\title{
EKONOMICKÉ ZHODNOCENÍ PROVOZU WEBOVÝCH APLIKACÍ
}

\section{Petr Rozehnal}

\section{Klíčová slova:}

Webová aplikace, webové stránky, přínosy, výdaje, hodnocení, webová analýza, měření.

\section{Key words:}

Web application, web pages, benefits, costs, evaluation, web analytics, measurement.

\begin{abstract}
Abstrakt:
Příspěvek je věnován problematice ekonomického zhodnocení provozu webových stránek. Vhodné podklady pro racionální posouzení aktuálního stavu a možného vývoje jsou pro rozhodování o dalším vývoji nepostradatelné. Diskutovány jsou možnosti kvantifikace přínosů a výdajů plynoucích z chodu webu. Stěžejní je přitom stanovení přínosů, zejména se zohledněním netransakčních zisků. Většina metod se omezuje na stanovení přínosů vyplývajících z provedených transakcí (typicky uskutečnění prodeje). V závěru je stručně zmíněna také strana výdajů.
\end{abstract}

\begin{abstract}
:
The paper is devoted to questions of economic evaluation of website running. Suitable bases for rational examination of actual state and possible development are essential for decision making within further development. Possibilities of quantification of contributions and expenses resulting from web running are discussed. Hereat contributions assessment is fundamental, especially with consideration of non-transaction profits. Majority of methods are namely limited to assessment of contributions resulting from realized transactions (executed sales typically). Aspect of expenses is also briefly mentioned at the close.
\end{abstract}

\section{Úvod}

V posledních letech, v období tzv. hospodářské krize, jsme svědky zostřeného pohledu na výdaje ekonomických subjektů. Klesající tržby znamenají menší přísun zisku, proto se pozornost výrazněji přenesla také na výdajovou stránku hospodaření. Prakticky každá organizace dnes má své webové stránky, jejichž provoz s sebou nese jisté výdaje. Př́spěvek bude zaměřen na ekonomické zhodnocení provozu webových stránek v kontextu výdajů a přínosů, které s jejich provozem souvisí. Hlavní důraz prritom bude kladen na zhodnocení př́nosů generovaných webovou prezentací.

Podklady pro ekonomické zhodnocení provozu webu jsou důležité pro rozhodování na všech úrovních řízení. Rozhodování o provozu, dalším vývoji webu, jeho strategickém směřování apod. by přitom měla vycházet z racionálního zvážení situace. Pro řídící pracovníky jsou často rozhodující odpovědi na dvě otázky: jaké budou přínosy a kolik to bude stát? [1]

V obecné rovině jde tedy o kvantifikaci př́nosů na straně jedné a výdajů na straně druhé. Obtížné je stanovit způsob měření. K problematice se vyjadřují mnozí autoři např.[2].

Možnost provádění webové analýzy jsou v dnešní době dostupné, rozsáhlé a poskytují dostatečné vstupní podklady pro další úvahy. Z ekonomického pohledu je často nutné vhodným způsobem definovat ekonomický měřitelné výsledky. V př́ipadě webových aplikací (stránek) nemusí být stanovení metrik pro měření jednoduché. Vycházet může ze specifických potřeb provozovatele. Takto je uvedeno např. v [3], kde je problematika řešena pro stránky, 
které negenerují transakce. Transakce jako měřitelná akce provedená za strany návštěvníka (zakoupení zboží, stažení SW apod.). Kvantifikace přínosů u netransakčních stránek je problematická. Uváděno je také rozdělení přínosů generovaných webovými stránkami na: [1].

- hmotné (orig. Tangible Benefits) - dobrá kvantifikace a vyjádření finančního přínosu,

- nehmotné - ty, u nichž je peněžní vyjádření obtížné.

Pokud chceme hodnotit př́nosy a výdaje na provoz webových stránek, je dobré definovat důvody jejich provozu. Jaké jsou důvody pro provoz webových stránek (mimo jakousi formální povinnost a módní trend)? Domnívám se, že v současné době lze vydefinovat dva základní cíle webových prezentací:

- Informační funkce - poskytování informací souvisejících s provozem organizace.

- Prodejní funkce - prodej výrobků, služeb je primárním cílem webových stránek, většinou doplněn o informační funkci, která prodej podpoří či umožní.

Informační funkci můžeme považovat za primární, vždyt' je Internet jako médium označován jako informační sít'. [4] V době tzv. informační společnosti má informace svou cenu, ačkoliv její stanovení může být velmi obtížné. Jednoznačně to dokazují také závěry studie BCG (The Boston Cosulting Group, Inc., viz [5]), kde se mj. uvádí príímá souvislost mezi informacemi získanými na Internetu a následným rozhodnutím o koupi zboží [5]. Ke stanovení této ceny, se vrátím v dalším textu. Nutno poznamenat, že forma přenosu informací, může nabývat několika podob. Pro potřeby tohoto př́íspěvku jsou aktuální následující formy.

- V nativní podobě formátů použitelných v prostředí služby World Wide Web tj. text, grafika, animace, video.

- Formou stažení souboru, který není svým principem určen pro prostředí World Wide Web.

Prodejní funkce souvisí s informačním cílem a svým způsobem, ho z pohledu komerčních organizací završuje. Internet jako prodejní kanál hraje stále důležitější roli a to ve všech formách B2B, B2C a dalších. [6]

Obě uvedené funkce představují potřebu vybudování webu a jeho následného provozu. Včetně pravidelných aktualizací, kontroly stavu a stanovení dalšího směřování. Takto investované prostředky by měly mít své opodstatnění a měly by být porovnatelné s př́nosy, které plynou z provozu webu. Z dlouhodobé perspektivy může být důležitá také celková hodnota webu. Webové stránky představují aktivum společnosti stejně jako ostatní majetek. A v tomto směru může být také předmětem obchodu. Nejde pouze o cenu dané domény (jak známo hodnota atraktivních domén je poměrně často diskutována), ale také o další atributy, které v souhrnu budou přispívat k celkové ceně. Zmínit můžeme návštěvnost, optimalizaci na klíčová slova, množství zpětných odkazů apod. U vybraných atributů jde o dlouhodobě a cílevědomě budovaný výsledek, který s sebou nese určitou hodnotu. ${ }^{1}$ Je zřejmé, že $\mathrm{v}$ takovém prrípadě bude výsledná cena webových stránek stanovena jinak než ocenění přínosů stránek za určité období. At' už hodnotíme web stránky z toho či jiného důvodu, zůstává základní otázka: jak hodnocení provést? Z ekonomického pohledu je nutná konverze různých měřitelných podkladů na jednu platformu, v tomto smyslu finanční. Uved'me jednoduše představitelný faktor množství návštěvníků daného webu. Samotné číslo uvádějící počet návštěvníků pak musíme převést na odpovídající hodnotu vyjadřující finanční hodnotu. Odtud pak plyne potřeba stanovení faktorů, které ovlivňují výsledek, stanovení poměru jejich váhy

\footnotetext{
${ }^{1}$ Př́́kladem trhu pro nákup a prodej webu může být http://www.buysellwebsites.com/.

Př́ḱladem ohodnocení webu pak mohou být http://www.websitevalue.co.uk, http://www.glurk.com/ a další.
} 
atd. V dalším textu se pokusím o návrh přístupu k hodnocení přínosu webových stránek a stanovení relevantních faktorů, včetně jejich kvantifikace.

\section{Hodnocení vyhledávačů}

K výše uvedenému ekonomickému pohledu na hodnocení webových stránek dodejme alespoň ilustrativně jiný úhel pohledu. Historicky je hodnocení webu důležité u hybných sil dnešního Internetu - internetových vyhledávačủ (např. Google, Bing, Yahoo nebo český Seznam). Pro potřeby definované v tomto materiálu jsou však způsoby hodnocení stránek užívané v těchto search enginech nedostačující. Hodnocení je prováděno se zcela jiným záměrem.

V rámci vyhledávačů jde o hodnocení relevance zadaného dotazu v kontextu obsahu známých webových stránek. A následně jejich seřazení jako výsledku vyhledávání. Tvůrci vyhledávačů se s nutností seřadit výsledky vypořádali sestavením algoritmu, který zahrnuje dílčí parametry hodnocení. Parametry mají být poskládány tak, aby vyjadřovaly „kvalitu“ stránky v kontextu vyhledávaného výrazu. Otevřeně přiznejme, že obecně nebylo dosaženo stavu, kdy by stránky byly objektivně zhodnoceny. Ani to není možné s ohledem na komplikace při definování pojmu kvalita s ohledem na množství stránek, témat a jejich diverzifikovanost. Bylo však dosaženo jednotného postupu aplikovaného demokraticky na všechny stránky a řadicí algoritmus je dále zdokonalován tak, aby i pojem kvality byl výsledku co nejbližší. Ačkoliv takto prováděné hodnocení je zaměřeno zcela jinak, může pro nás být v obecné rovině výchozí. Základní myšlenky jsou přenositelné. Zejména z pohledu př́istupu k hodnocení.

- Nelze stanovit univerzální způsob hodnocení, který by vyhověl všem aspektům, které mohou být pro výsledek relevantní. Těchto faktorů je celá řada a mohou být velmi individuální, jsou závislé na potřebě subjektu, který hodnocení provádí.

- Pro hodnocení je potřeba stanovit hodnotící algoritmus, který bude aplikován na měřený subjekt. Předpokladem jsou vstupní data z webové analytiky.

- Sestavený algoritmus (tř̌ebaže nedokonalý) měří všem stejně. V tomto směru jde o objektivní měření.

- Pro hodnocení je nezbytné vnímat celkový kontext stránek. Tyto externí vlivy mohou výrazně ovlivnit výsledek. Jde zejména o pozici v rámci ostatních stránek, prolinkování, obsah, role a cíl stránek apod.

- Na hodnocení může mít vliv také technická realizace.

Je velmi obtížné stanovit optimální algoritmus pro hodnocení s ohledem na heterogenitu hodnocených objektů. $Z$ toho důvodu jsem se pro ekonomické zhodnocení omezil na: 1) stanovení algoritmu, který bude obsahovat subjektivní prvky (posouzení konkrétního hodnotitele), 2) vybrané faktory, které by mohly ovlivnit výsledek, jsem vynechal (týká se to zejména těch faktorů, které jsou v hodnocení promítnuty nepřímo) a konečně 3) půjde o hodnocení výnosů stránek (ne hodnoty stránek).

\section{Hodnocení přínosů}

Výchozí teze pro hodnotící algoritmus jsou následující: hodnocena bude vždy samostatná stránka jako celek, pro celkový výnos budou dílčí výnosy sumarizovány, výsledná jednotka hodnocení bude finanční, algoritmus bude koncipován jako otevřený, parametrizovatelný dle nastavení vybraných proměnných. Př́ikladem podobného typu hodnocení je ukazatel Index USD ve službě Google Analytics (7). Výpočet ukazatele je definován jako:

Index $U S D=($ hodnota cíle + př́jem $) /$ počet jedinečných zobrazení stránky 
V rámci analýz je tento ukazatel určen pro orientaci důležitosti stránky v rámci ostatních stránek webové prezentace. Ve smyslu výše definovaném patří mezi ukazatele, který obsahuje subjektivní prvek. Jde o ohodnocení konverze a její definování. Jde o ukazatel jedinečný pro danou stránku.

Pro sestavení vlastního hodnocení nyní definuji základní faktory, relevantní pro tvorbu algoritmu.

- Přínos stránky na základě ekonomického zvážení. Jde o subjektivní veličinu stanovenou kompetentní osobou. Hodnota samotná však může být podložena ekonomickými údaji. U webových stránek můžeme očekávat tř̀i základní typy operací, na jejichž základě dojde ke stanovení přínosu - provedení obchodní transakce (odvození př́nosů vyplývá z průměrné ceny zakázky resp. z ní odvozeného zisku), stažení vybraných dat $\mathrm{z}$ webu (analogie distribuce informací v podobě manuálu, tisku brožury, distribuce softwaru apod.), informační hodnota pro zákazníka (dle zaměření jde o variantu zajišt'ující funkci letáčku, reklamy apod.).

- Počet zobrazení dané stránky, jako parametr vyjadřující návštěvnost.

- Obecné hodnocení stránky od jednotlivých vyhledávačů (např. PageRank).

- Hodnota stránky, na kterou stránka přivádí návštěvníky (vyjádřeno počtem těchto návštěv). Pokud stránka přivádí návštěvníky na další stránku, je pro web důležitá nebot' zajistí jejich další přítomnost na webových stránkách. Část hodnoty takto navštívené stránky by se měla přenést na odkazující stránku.

- Provedení cílové konverze, která vyjadřuje, kolik návštěvníků provedlo definovanou akci - např. realizovalo objednávku zboží, ale také stažení souboru (viz také první odrážka tohoto seznamu).

- Počet příchozích linků na danou stránku. Hyperlinky hrají v hodnocení webových stránek důležitý parametr, proto by měl být součástí hodnoty stránky. Zajištění kvalitního odkazu je navíc vázáno na vynaložení určitých nákladů.

- Stránka, která je první stranou na kterou návštěvníci přichází z prostředí Internetu (tzv. landing page). Stránka je zdrojem návštěv webu, přivádí dalšího návštěvníka.

- Pozice stránek ve vyhledávačích na klíčová slova. Stránky umístěné na čelních pozicích vyhledávačů jsou potenciálem pro zajištění dalších návštěvníků.

Na základě těchto faktorů jsem odvodil hodnotící algoritmus, kde $v$ je hodnota stránky, $n$ je počet zhlédnutí stránky, $n_{i p}$ je počet zhlédnutí tzv. landing page, $v[N]$ je hodnota stránky $N$ a $m[N]$ je počet návštěvníků, kteří navštívili stránku $N$ ze současné stránky.

$$
P P=v . n+\frac{v}{2} n_{i p}+0.1 \sum_{N=1}^{K} v[N] m[N],
$$

Počet zobrazení stránky plní v algoritmu stejnou roli at’ se jedná o stránku, která realizuje nebo potvrzuje provedení konverze nebo o stránku, která svým zobrazením plní informační funkci. Pokud je cílem stažení souboru, mělo by zobrazení stránky být nahrazeno počtem stažení. Pokud by bylo potřeba ohodnotit zvláště i zobrazení stránky bez provedení operace stažení, pak by se obě hodnoty (výnos ze zobrazení a výnos ze stažení sečetly).

Pro zjednodušení je $\mathrm{v}$ algoritmu abstrahováno od hodnocení stránky vyhledávači (např. uváděný PageRank) a hodnocení pozice ve vyhledávačích na konkrétní výraz. Nicméně je potřeba si uvědomit, že tyto dva faktory jsou obsaženy $\mathrm{v}$ počtu prríchozích návštěvníků. Podobně je vypuštěn parametr cena za link. Jednak je jeho význam rozložen do počtu návštěvníků, jednak je významnější pro hodnotu stránky (než pro výnos stránky). Přesto by bylo zajímavé vyčíslení ceny za příchozí link, nebot' zpětné odkazy v zásadě získáváme třemi 
způsoby: přímé získání odkazu, podporou pro tvorbu odkazu pomocí třetích osob nebo pomocí třetích osob bez vlastního přičinění. První dvě varianty s sebou nesou náklady, proto se dá očekávat snaha o jejich ekonomické zhodnocení.

V mechanismu přechodu části hodnoty cílové stránky na stránku na ni odkazující (která ji tak předává část provozu - návštěvníky) předpokládám přenos 10 procent. Parametr lze upravit dle uvážení. Zvýhodněny jsou také stránky, které jsou pro daný web vstupní. Za každou takto zobrazenou stránku se načítá 1,5 násobek její hodnoty.

Při aplikaci hodnotícího algoritmu dostaneme jak rozdělení výnosů jednotlivých stránek, tak celkový souhrn za celý web. Další analýzou bychom mohli hledat také další závislosti, např. korelaci mezi hodnotou stránky a jejím výsledným přínosem pro celkový výnos webu. Výsledky by byly zajímavé zejména u stránek, které nesou informační hodnotu. Mohli bychom kontrolovat využití potenciálu stránek. Z výsledků rovněž vyplývá, že i stránka, která nebyla ohodnocena, generuje zisk. Důvodem je přenos části hodnoty z jiných stránek, kterým zajistila část provozu. Otevřenou otázkou zůstává stanovení velikosti přenášené části výnosů. Domnívám se, že je to opodstatněné, nebot' je součástí webu a proto přispívá k jeho prosperitě. Ačkoliv její vliv je dle ohodnocení zanedbatelný (rovný 0). Nabízí se otázka. Proč provozujeme stránku, která nepřináší zisk? Teoreticky na ni nemůžeme odpovědět, nebot' jsme vyrobili a provozujeme něco co je v podstatě zbytečné. V praxi však je situace jiná. Na webech jsou opodstatněné také stránky, které „de facto“ nic nepřináší, ale jejich opodstatněnost vyplývá z vytváření kontextu, prostředí bez kterého by podstatné stránky nemohly existovat. Stránka uvedená v příkladu nemusí mít pro provozovatele přímo hodnotu, ale přesto je součástí systému a slouží tak svému účelu (což potvrzuje zisk generovaný odkazováním na jiné „hodnotné“ stránky. Na druhé straně, by měla odpovědná osoba zvážit poměr mezi stránkami, které mají svou hodnotu a těmi, u nichž hodnotu nemá cena stanovovat, protože jsou pro web pouze podpůrné. Empirické zhodnocení mechanismu je uvedeno $\mathrm{v}[8]$.

Důležitou součástí takto pojatého hodnocení je volba stránek, které budou hodnoceny. S ohledem na ruční práci při tomto výběru a pro ohodnocení se pro praktické užití musíme omezit na ty stránky, které jsou pro nás důležité (natolik, že je do analýzy zahrnujeme). Např́klad na realitním serveru budou hodnoceny stránky, které nesou primární informaci o prodávané nemovitosti a hlavní stránka webu se stránkami jednotlivých kategorií. Hodnoceny nemusí být stránky, které nemají přímý dopad na obchod. Jako př́klad uved'me stránky věnované historii firmy, informace o nakládání s daty klienti̊, zajímavé odkazy, doplňující informace apod.

V rámci uvedeného hodnocení jde pouze o vyčíslení výnosů souvisejících se samotnou funkcí stránek. Ke generovaným výnosům však mohou být přidány další výnosy plynoucí z provozu. Pro př́klad výnosy za umístěné reklamy, výnosy plynoucí z dat získaných od návštěvníků.

\section{Hodnocení výdajů}

Po vyčíslení výnosů z provozu webových stránek se nyní podívejme na nákladovou stránku. Také zde je několik úskalí, které brání jednoznačné identifikaci nákladů. Předně si musíme uvědomit, že náklady se budou výrazně lišit při vývoji stránek a při jejich údržbě. Ve smyslu udržování aktuálnosti. Období vývoje (tyto nákladové položky) musí být pro další ekonomické analýzy zohledněno. Pro posouzení může být důležitý také rozsah a frekvence změn na webových stránkách. Tyto a další faktory mohou výrazně změnit pohled na stanovení nákladových položek.

Pro zhodnocení nákladové stránky provozu webových stránek se nám nabízí dva prrístupy. 
- První, kde budeme hodnotit náklady na provoz jednotlivé stránky (stejně jako u vyčíslení přínosů - uvedeno výše).

- Druhý, kde bychom vyjádřili náklady na provoz stránek jako celku.

Domnívám se, že je vhodnější druhá varianta. Jako hlavní důvody uvádím následující. Nákladové položky jsou snadněji identifikovatelné (v porovnání s přínosy) na celkové úrovni. U prŕínosů jsem se $\mathrm{v}$ rámci výše uvedeného přístupu snažil zahrnout také přínosy u stránek, které generovaly přínos na základě informační hodnoty. $\mathrm{V}$ rámci nákladů takový př́istup není nutný, ty jsou většinou dobře dohledatelné a zdokumentované.

Naopak těžko bychom rozdělovali nákladové položky mezi jednotlivé stránky např. náklady na webhosting, platba za doménu, příplatek za množství dat apod. Výrazné komplikace by nastaly také u stanovení nákladů na provoz jednotlivé stránky. Zvažme např́klad stanovení nákladů na autora obsahu stránky při vzniku a dále při aktualizaci tohoto obsahu.

Přesto nelze vyloučit, že v určitých případech by stálo za úvahu doplnit stanovení nákladů na provoz webových stránek individuální náklady na úrovni jednotlivých stránek (nebo jejich seskupení dle vybraných kritérií).

Autoři zabývající se touto tématikou uvádějí nejčastěji tyto náklady související s provozem webu (řazeno náhodně): vývoj webu, webhosting, cena domény, správa webu, zajištění zpětných odkazů, vedení reklamních kampaní, aktualizace obsahu apod. Po očištění o mimořádné náklady (viz nap̌r. prvotní vývoj) lze nákladové položky rozdělit a poměrně přesně kvantifikovat. Většina těchto položek a dalších nákladů pokrývá web jako celek. To doplňuje výše uvedený přístup k vyčíslení nákladů.

\section{Závěr}

Výstupy měření prrínosů a výdajů jsou použitelné pro další analýzy provozu webových stránek. Typicky lze dovodit návratnost investic do této formy prezentace, stanovit, které části webu jsou z pohledu potřebných výstupů klíčové. Uvědomění si důležitosti jednotlivých části webu, možnosti zhodnocení přínosů vybraných oblastí apod. To, že pro realizaci je nutné zhodnotit přínos jednotlivých stránek webu, neznamená ocenění „všech“ stránek. Stejně dobře bude postup funkční pokud budou oceněny pouze klíčové stránky nebo mohou být oceněny množiny stránek (samozřejmě s úpravou vstupních dat z web analytiky, kde by rovněž muselo dojít ke spojení). Dále je možné uvedený postup kombinovat s běžně užívaným přístupem pro ekonomické zhodnocení u transakčně orientovaných webů (kde jsou data stanovena např. objemem prodeje, cenou zboží - tudíž jasně kvantifikována). Realizace by byla možná také v kombinaci s jinými metrikami ohodnocení klíčových přínosů.

Softwarová podpora uvedeného přístupu by rovněž umožnila snadnější realizovatelnost. Tyto a další podměty mohou být impulsem pro další rozpracování. Stejně jako úprava samotného algoritmu hodnocení tak, aby bylo hodnocení co nejpřsesnější.

Příspěvek si kladl za cíl podpořit možnosti ekonomického hodnocení provozu webových stránek. Ačkoliv mnohé přínosy je v podstatě nemožné kvantifikovat, mohou výrazně ovlivňovat hospodářské výsledky provozovatele. 


\section{Literatura:}

[1] CROWDER, R., WILLS, G., HALL, W. Hypermedia maintenance support applications: Benefits and development costs. Computers in Industry. 7, September 2005, sv. 56, s. 681698. ISSN 0166-3615.

[2] PARIS, C.L., COLINEAU, N.F.; WILKINSON, ROSS G. A cost-benefit method for webbased information systems. In 20th ACM conference on Hypertext and hypermedia.Torino, Italy: ACM New York, NY, USA, 2009. s. 353-354. ISBN 978-160558-486-7.

[3] KRYL, M. Jak zvolit KPI pro netransakční web. [Online] [Citace: 15. 03 2011.] Dostupný z WWW: <http://www.slideshare.net/krylm/jak-zvolit-kpi-pro-netransakn-web.>

[4] VESELÝ, V. Informační management v ére Internetu. [Online] [Citace: 10. 2 2011.] Dostupný z WWW: <http://www.inforum.cz/archiv/inforum1999/prednasky/vesely.htm.>

[5] ČERVENKA, L. a kol. Země internetová. Praha: The Boston Cosulting Group, Inc., 2011. s. 35, Studie.

[6] TVRDÍKOVÁ, M. Aplikace moderních informačních technologií v řízení firmy. Praha: Grada, 2008. s. 176. ISBN 978-80-247-2728-8.

[7] CLIFTON, B. Google Analytics. Brno: Computer Press, 2009. s. 334. ISBN 978-80-2512231-0.

[8] ROZEHNAL, P. Revenue from Web Pages and Possibilities of Evaluation. In ECON. 2011, Sv. 1, s. 62-68. ISSN 1803-3865.

\section{JEL M15, M19, C58}

\section{Ing. Petr Rozehnal, Ph.D.}

Odborný asistent Katedra aplikované informatiky

VŠB-TUO, Ekonomická fakulta

Sokolská třída 33

Ostrava 1, 70121

petr.rozehnal@vsb.cz 